кейс-технологій на формування критичного мислення учнів та майбутніх учителів; критичне мислення в контексті розвитку соціальної компетентності учнів тощо.

\title{
Література:
}

1. Вашуленко М., Васильківська Н., Дубовик С. Українська мова та читання: Підручник для 3 класу закладів загальної середньої освіти (у 2-х частинах). Частина 1. Київ: Освіта. 2020. 160с.

2. Bloom, B.S. (Ed.). Taxonomy of educational objectives: The classification of educational goals, by a committee of college and university examiners. Handbook 1: Cognitive domain. New York: David McKay. 1956. URL: https://www.uky.edu/ rsand1/china2018/texts/Bloom\%20et\% 20al\%20-Taxonomy\%20of\%20Educational\%20Objectives.pdf.

3. Foster, Ruth. Analogies for critical thinking. Grades 1-2. Garden Grove. California. Teacher Created Resources. 2018. 64.

4. Scholastic Success with $3^{\text {rd }}$ grade. Workbook: Math, Reading, Writing, Grammar, Maps. New York. Toronto. London. Auckland. Sydney. Scholastic Teaching Resources. 2003. 416.

5. Stobaugh, Rebecca. Assessing critical thinking in elementary schools: meeting the common core. Routledge, Taylor \&Francis Group New York London, 2013. 160.

DOI https://doi.org/10.30525/978-9934-588-80-8-2.13

\section{СПОСОБИ ПРЕЗЕНТАЦІЇ ФРАЗЕОЛОГІЧНОГО МІНІМУМУ ІНОЗЕМНИХ СТУДЕНТІВ-МЕДИКІВ}

\author{
Кушнір I. М. \\ кандидат педагогічних наук, доцент, \\ доцент кафедри мовної підготовки 1 \\ Навчально-науковий інститут міжнародної освіти \\ Харківського начіонального університету імені В. Н. Каразіна \\ м. Харків, Україна
}

Іноземні студенти українських медичних ЗВО здобувають освіту іноземною для них мовою (українською), яка набуває інструментальної та світоглядної функції у комунікативній взаємодії з чужоземним мовно-культурним середовищем і в навчально-пізнавальній діяльності. Тож доленосним фактором $\epsilon$ володіння іноземною (українською) мовою, а побудова та організація системи навчання української мови 
набуває функції мовної освіти. Разом із засвоєнням фонетичного, лексичного, граматичного, синтаксичного рівнів української мови іноземні студенти-медики мають оволодіти мовленнєвими уміннями використання фразеологічних одиниць, тому що фахова мова медицини $€$ образною та метафоризованою. У процесі навчання української мови необхідно формувати в іноземних студентів-медиків знання певної кількості фразеологічних одиниць (відповідно до рівня засвоєння української мови як іноземної), а також уміння користування такими мовно-культурними одиницями в ситуаціях науково-академічної та навчально-професійної комунікативної взаємодії. Фразеологічний мінімум ще не виокремлений зі складу лексичних мінімумів, лише доповнює їх $[1 ; 2]$. Для визначення змісту фразеологічного мінімуму, необхідного у навчанні української мови як іноземної, доцільно враховувати когнітивні, структурно-семантичні, функційно-комунікативні параметри фразеологічних одиниць.

Урахування національно-культурних, функційно-прагматичних i ментально-когнітивих параметрів фразеологічних одиниць необхідне для відбору фразеологічного мінімуму медичного дискурсу.

У відборі українського фразеологічного мінімуму для інокомунікантів традиційно застосовують такі критерії: «лінгвокраїнознавча та комунікативна цінність, доступність, нормативність, пов'язаність із граматичним i лексичним мінімумами, можливість витлумачити фразему стисло і знайомими словами, прозора внутрішня форма, наявність відповідника в рідній мові, екзотичність, орієнтація на сучасну дійсність» [2, с. 83]. Під час виокремлення фразеологічних одиниць, необхідних для навчання української мови іноземних студентів-медиків (відповідно до рівня оволодіння мовою від В1 до В2) необхідно особливо враховувати лінгвокультурниий потенціал фразеологічних одиниць, їхню екзотичність, пов'язаність із граматичним та лексичним мінімумами. У медичному дискурсі функціонують такі види фразеологічних одиниць, як термінні вислови та мовленнєвоетикетні формули (за класифікацією Л. Булаховського, В. Телії, Г. Удовиченко).

Урахування когнітивних, структурно-семантичних, функційнокомунікативних параметрів фразеологічних одиниць дозволить створити ефективну презентацію змісту професійно-орієнтованого фразеологічного мінімуму медичного дискурсу для іноземних студентів, які вивчають українську мову як іноземну від рівня В1 до рівня В2. Аналіз мовного матеріалу показав, що доцільно обрати гніздове пред'явлення та мовно-ілюстративне, яке демонструє образність медичних термінних метафор на основі асоціативної кореляції 3 лінгвокультурними та ментально-когнітивними реаліями. Мовленнєво-етикетні кліше медичного дискурсу доцільно розподіляти за комунікативно-функ56 
ційними ознаками лінгвотерапевтичності й сугестивності. Залишається відкритим питання щодо обсягу українського фразеологічного мінімуму, що $є$ перспективою подальших наукових розвідок.

\title{
Література:
}

1. Баран Я.А., Зимомря М.І., Білоус О.М., Зимомря I.М. Фразеологія: Знакові величини. Вінниця: Нова книга, 2008. 255 с.

2. Кузь Г. До проблеми формування фразеологічного мінімуму. Теорія і практика викладання української мови як іноземної. 2013. Вип. 8. С. 122-129.

DOI https://doi.org/10.30525/978-9934-588-80-8-2.14

\section{ЦИФРОВИЙ ПОСТУП ЗАКЛАДІВ ЗАГАЛЬНОЇ СЕРЕДНЬОЇ ОСВІТИ УКРАЇНИ}

\author{
Литвинова С. Г. \\ доктор педагогічних наук, старший науковий співробітник, \\ заступник директора з наукової роботи \\ Інститут інформачійних технологій $і$ засобів навчання \\ Національної академії педагогічних наук України \\ м. Київ, Украӥна
}

Широкомасштабне впровадження цифрових технологій в закладах загальної середньої освіти (3ЗСО) України відбувалося в три етапи (рис. 1.):

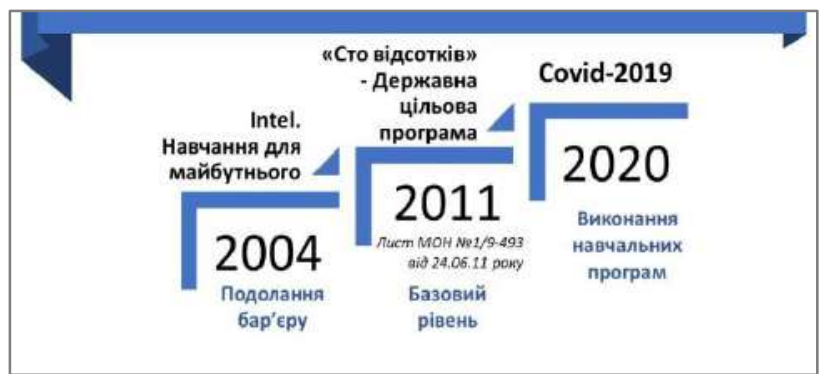

Рис. 1. Широкомасштабне впровадження цифрових технологій в школах України 